\title{
Towards the Creation of Monitoring and Evaluation Tool for Values Education: An Exploratory Survey of Values of Grade 1 Students in West I School District City Schools Division of Cagayan De Oro
}

\author{
Melody Fe B. Caperida-Obrador \\ Renato L. Base
}

\begin{abstract}
The Department of Education's (DepEd) Order 41, S. 2003 stipulated the importance of values education in the Basic Education Curriculum. It further stated for a need to "meaningfully integrate values development" through the different subjects being taught to students. Eighteen years after the said Department Order was issued, the lingering question facing schools right now is how do we know that we have developed desirable values to our students? To objectively and impartially answer this question entail that DepEd has a scientifically acceptable monitoring and evaluation tool that can track the progression and regression of values that we taught to our students. Unfortunately, there is no such kind of tool so far. It is on this context, that this study was conducted with the end in mind of advancing the idea that now is the time for DepEd particularly the City Schools Division of Cagayan de Oro to start contemplating in the development of a tool that can monitor and evaluate the progression and regression of those desirable values that we have taught to our students. In response to this, an exploratory survey was conducted to Grade I students in West I School District, which was then disaggregated in terms of their gender. The result had shown that out of the six values that were included for testing, only three attitudinal and behavioral indicators, namely, politeness, cordiality, and honesty in which male and female Grade I students significantly differ. Due to the delimitation being self-imposed in this exploratory survey, the study did not capture the different demographics of the children, which if done, could provide and extensive as well as intensive insights of these children's differences relative to the values being explored. The study concluded that all values acquired by the child are reflective of the dominant values in the family of the child and in the community in which the child belongs. Therefore, being able to ascertain and profile the values of our school children, it can provide the teachers and the school an insight of the dominant values that are either positive or negative that students are imbibing in their respective families and in their community. On this, it is then possible to come up with program intervention within the context of the core values that DepEd had wanted to promote, namely, maka-Diyos, ma-katao, makakalikasan and makabansa. In that note, the study recommended that it is now time for DepEd to come up with a monitoring and evaluation tool to be used during the entire elementary and high school years of children that can track the progression or regression of core values that DepEd wanted to inculcate to its school children.
\end{abstract}




\section{INTRODUCTION}

School children undergo many kinds of transition that demands from them that they adopt to the new or altered environment (Bronfenbrenner 1979); and the schools are one of these environments, which they have to undergo and, therefore, must adapt, whether they like it or not. For this reason, we can fairly say that indeed the school is the major socialization institution of school children. As a socialization institution, children adjustments is in a constant state of flux. In other words, the process of finding and adopting modes of attitudes and behavior suitable to the school environment or the changes that are taking place in the school environment is likewise changing. Undeniably, this have an impact to children's values and their attitudes and behavior. It is a commonly accepted knowledge that the school environment is where the child learn how to manage day-to-day interactions not only with peers but also with the teacher. The children's interaction with the teacher opens up a window, so to speak, in which we can be provided with a glimpse of children's attitudes and behavior towards their teachers. We need to note that the attitudes and behavior of school children are reflections of the kind of values they have imbibed in their social environment and in the course of their social interaction cf. (Clay and Fleischmann 2012). Therefore, if we want to assess the values of our students, which are intangible, then, the best approach to do it is through the profiling and measurement of their attitudes and behaviors, which are tangible and which are manifestations of the values they have imbibed in their family and community.

In view of this, we find it imperative to identify the attitudes and behaviors of Grade 1 students so that possible profiling can proceed. This initial profiling is intended to pave the way for a more comprehensive profiling that must be done to address the challenges as set forth by DepEd Order 41, S. 2003 - Values Education in the Basic Education Curriculum. Therefore, this is not intended to be comprehensive in nature but rather an exploratory survey in order to trail blaze a path so that an effective values education monitoring tool of students at the elementary level can be done. Furthermore, we need to emphasize that to come up with Values Profile for each school children particularly at the elementary level can facilitate the monitoring of values education in terms of how strong we have inculcated the values, and whether the values education we do to our students is gaining the high ground. Hence, a profile of this kind is crucial for values education teacher. Having this kind of profile, can enable values education teacher to have an overview in the course of an entire school year whether those attitudes that manifest at the beginning of the year which have been initially identified as unwholesome have significantly changed for the better or for the worse, at the end of the school year. In this way, the values education teacher and more importantly the school head will have an idea whether the values that is explicitly and implicitly imparted by the school to help shape the child's moral dimensions in accord to the core values that DepEd wanted to promote have been effective or not. Given the fact that there is no such a monitoring and evaluation tool to monitor the progression or regression of these values, make it the more compelling for DepEd to craft such a tool. It is this gap that this exploratory survey was conducted to serve as catalysts to our school administrators that now is the opportune time for the City Schools Division of Cagayan de Oro to have such a tool since if our schools division is able to come up with such a tool, it would be the first of its kind in DepEd. As a result the City Schools Division of Cagayan de Oro will be trailblazing a path for other schools division to follow.

\section{SIGNIFICANCE OF VALUES PROFILING}

This is an exploratory survey on the profiling of Grade 1 students that limits to six values as made manifest in their attitudes and behavior towards the teacher. At the outset we need to emphasize that attitudes and behavior were chosen as proxy indicators of values based on the premise that they are reflective of the values of the person, which are of course intangible. There are only six attitudinal and behavioral indicators 
that were being utilized to benchmark the values among Grade 1 students; and, of course, it is far from being comprehensive.

The rationale behind this survey is to advocate for a need to come up with Values Profile at the starts of the school year and such profile must be updated at the end of the school year so that the teacher can have an idea of the progression or regression of the values being taught to students at the end of a given school year; and this profiling should again be conducted when, for instance, the Grade 1 students advances to the next level. The same process of profiling must be done, that is, at the beginning of their Grade 2 school-year and at the end, and so on and so forth until they will graduate to their elementary years. The data and information that can be generated in this values profiling will provide the teachers and the school administrators relevant information relative to any significant changes in the development of children's moral dimensions as they move from Grade 1 to Grade 6. Of course, this kind of tool is in response to DepEd Order 41, S. 2003 Values Education in the Basic Education Curriculum - in which it stated for a need "to properly evaluate the result of interventions conducted both inside and outside the classroom". We need to underscore that the present system of monitoring children's values through the use of School Form 9 that is Progress Report Card or is not enough, notwithstanding the fact that such is not scientific.

One avenue by which the City Schools division of Cagayan de Oro will be able to address the challenge set forth in the aforesaid DepEd Order is to have a values profile of school children's students using a tool the rigors of scientific testing for us to be able to assess whether the values that is being explicitly and implicitly imparted during the course of values education really made a significant dent in the formation of the children's moral dimensions, as envisioned in the said DepEd Order. This tool that is being proposed here can be likened to that of Phil-IRI. If DepEd was able to come up with such a sophisticated tool that measures the reading readiness of the child, why not also come up with a tool that measures the progression and regression of the child's values in the context of the four core values of DepEd?

\section{SURVEY METHODOLOGY}

As an exploratory study, there were six attitudinal and behavioral indicators in which this Values Profiling survey is anchored. These are: 1) Politeness; 2) Cordiality; 3) Generosity; 4) Humility; 5) Respectful; and 6) Honesty. We need to acknowledge though that these six attitudinal and behavioral indicators were conceived and took its cue from the Bristol Social-Adjustment Guides - No. 1.

Given this is an exploratory survey, we subjected the questionnaire to a test of validity but not of reliability. We used face validity and item-validity for this. The survey was conducted to One-hundred eighty-one (181) Grade 1 students during the school-year 2020-2021 in the four Elementary Schools in West I School District in the City Schools Division of Cagayan de Oro, The Philippines. One-hundred eighteen (118) of which were males and sixty-three (63) were females.

In the data analysis, we used frequency counts and percentage and applied the Chi-square test to find any significant difference between the gender values at .05 level of significance. The following hypotheses we tested are as follows. There is no significant difference between male and female on the values of politeness, cordiality, generosity, humility, respectfulness, and honesty. 


\section{FINDINGS}

The following were the findings of the study, as shown in the foregoing summary table.

\begin{tabular}{|c|c|c|c|}
\hline \multicolumn{4}{|c|}{ Summary Results of the Chi-square Test of Difference } \\
\hline \multirow[b]{2}{*}{ Values } & \multicolumn{2}{|c|}{ Chi-Square Test of Difference } & \multirow[b]{2}{*}{ Interpretation } \\
\hline & $\begin{array}{c}\text { Chi-square } \\
\text { value }\end{array}$ & p-value & \\
\hline Politeness & 8.393 & $0.0486<.05$ & $\begin{array}{l}\text { Reject null hypothesis. There is } \\
\text { significant difference between } \\
\text { male and female' politeness. } \\
\text { Girls tends to be polite than } \\
\text { boys. }\end{array}$ \\
\hline Cordiality & 15.294 & $.00158<.05$ & $\begin{array}{l}\text { Reject null hypothesis. There is } \\
\text { significant difference between } \\
\text { male and female' cordiality. } \\
\text { Girls tends to be cordial than } \\
\text { boys. }\end{array}$ \\
\hline Generosity & 9.046 & $.03997<.05$ & $\begin{array}{l}\text { Reject null hypothesis. There is } \\
\text { significant difference between } \\
\text { male and female' generosity. } \\
\text { Girls tends to be generous than } \\
\text { boys. }\end{array}$ \\
\hline Humility & 1.448 & $0.91899>.05$ & $\begin{array}{l}\text { Accept null hypothesis. There is } \\
\text { significant difference between } \\
\text { male and female' humility. }\end{array}$ \\
\hline Respectful & 6.374 & $0.1729>.05$ & $\begin{array}{l}\text { Accept null hypothesis. There is } \\
\text { significant difference between } \\
\text { male and female' respectfulness. }\end{array}$ \\
\hline Honesty & 7.993 & $0.04616<.05$ & $\begin{array}{l}\text { Reject null hypothesis. There is } \\
\text { significant difference between } \\
\text { male and female' honesty. Girls } \\
\text { tends to be honest than boys. }\end{array}$ \\
\hline
\end{tabular}

\section{DISCUSSIONS}

Ideally, the overall thrust of values education in DepEd should aspire to level off the differences between male and female in a given cohort. This is especially significant if we want to find out whether the manner in which we conscientize our students relative to four core values of DepEd is a successful one or not. And, this can be done at the cohort and at the individual level, if values profiling is being done particularly during the start of a school year and at the end of a school year, which covers all grade level. A profile that includes 
but not limited to the abovementioned salient points is a good starting point for teachers to have an idea of why and how the children under their care is progressing or regressing in a given core values of DepEd.

Again, we need also to emphasize that attitudes and behavior is a reflection of a person's values (iEduNote 2021; Katz 1960; Kristiansen and Zanna 1988). However, values are intangible compared to attitudes. Hence, to be able to ascertain the extent of which Grade 1 students have been conscientized with the core values being taught by DepEd through Values Education, then we need to measure what is tangible; and, that is, through the student's attitudes and behavior that relates to the indicators of each of the four core values. Therefore, by measuring the student's attitudes and behavior it provides us a glimpse of the dominant values embodied in our Grade 1 students, say, in this instance (cf. Maio and Olson 1994). Given that the family in particular and the community in general is one of the primary sources of values of children, this is therefore suggestive that the values of Grade 1 students are reflective of the prevailing dominant values that can be found in their families and in their communities. But the teacher can only discern the children's values coming from their family and community and use it as a benchmark in its values education only when there is a good values profiling.

Although the attitudinal and behavioral indicators that were being measured here are far from being comprehensive, however, if a tool that really caters to measuring the core values of DepEd can be created or crafted such could give values education teacher at DepEd an idea as to the extent of conjunction or disjunction of the prevailing values inherent in the child with that of the core values. Having such insight is supposedly should be the basis in coming up with interventions.

We all knew that the four core values that must be inculcated to students by DepEd must are as follows maka-Diyos (pious/godly), ma-katao (humane), makakalikasan (nature lover), and makabansa (nationalistic). Likewise, we also knew that to objectively assess and measure these core values. We need also to come up with specific measurable attitudinal and behavioral indicators for each of these values. At this point in time, DepEd has still to craft these measurable indicators, which can be utilized in the coming up of an assessment and monitoring tool for values education.

Assuming that, for the sake of discussion, the six indicators as presented above are indicative of the makatao values; and, further, taking cue from the profiling presented above, we could now see a partial picture of the makatao values as embedded within our Grade 1 students personality traits (cf. Goldberg 1990). In this profiling, however, we need to note that if boys and girls significantly differ in those values, what could be its significance? It means that the magnitude of the effect of those values coming from the communities and families of these children have different level of influence to these boys and girls. Furthermore, this reveal that as young as these students are, they already have though unwittingly imbibed values, which they may have acquired through their life experiences, and their exposure to such experiences. It is on this aspect that values profiling becomes significant to DepEd values education. A good profiling of values can provide the teacher and school administrator on the extent in which a particular is progressing or regressing relative to the core values.

At such a young age, if these values could not be positively reinforced for good through DepEd's values education, of course, ultimately it will eventually affect the children's types of decision that they will make, 
how they perceive their environment, and their actual behavior (Lusk \& Oliver, 1974; Rokeach, 1973). How do we know that at the end of the school year that the values we taught to our students has been a success? What is our basis in saying that it is successful or not? Though we cannot discount the importance of teacher's observation, however, such an observation is subjective. Therefore, it should be complemented with something that can measure objectively attitudes and behaviors. It comes to our mind that if we have the Phil-IRI that can objectively measure the students reading level, why not come up with a tool that can measure the values we have inculcated to our students? Can we honestly say, based on data gathered that, at the end of their six-years of elementary education, these elementary graduates have been successfully conscientized by the four core values of DepEd? A successful conscientization of DepEd's core values will have a positive redounding effect to our society as a whole.

It is on this aspect that DepEd's values education should have a monitoring and assessment tool that can objectively measure the extent in which values have been successfully instilled from Grade 1 to Grade 6, and even up to their Junior and Senior High School level. If their values are monitored longitudinally using a scientifically accepted tool, then, the more confident we are to declare that DepEd's values education is successful and effective.

\section{CONCLUSIONS}

To sum up, although this study only used these six values as sample, nonetheless, it is a revelation, which for us profound on the extent of the similarity and differences of male and female Grade 1 students relative to the six values. Their similarity and differences in values are indicative of the degree of their exposure to experiences and events within their family, and in their community. A good values profiling can capture this. Lastly, values education is as crucial to our society as the other subjects that are being taught to our children from their elementary up to their senior high school years.

\section{RECOMMENDATION}

1) The DO 41, S. 2003 - Values Education in the Basic Education Curriculum - is now almost twenty years old. Hence, it is now timely for the Department of Education to come up with a scientific tool - same as that as the Phil-IRI that can measured objectively, and can be used for monitoring and evaluation relative to the progression or regression of our student's values.

2) In coming up with this tool, DepEd should come up with a measurable indicator anchored on the four core values.

3) To realize such a tool, the respective school's division can initiate and pilot such a tool and have it approved by the Regional Office for replication in the different schools' division in Region-X. The City schools of Cagayan de Oro can trailblaze a path in coming up with this tool. If successfully piloted, this can be the first of its kind in the Philippines.

\section{REFERENCES}

Bronfenbrenner, U. (1979). The ecology of human development. Cambridge, MA: Harvard University Press. 
Clay, Thomas, and Kenneth R. Fleischmann. 2012. "The relationship between human values and attitudes toward the Park51 and nuclear power controversies." Proceedings of the American Society for Information Science and Technology 1-10.

Goldberg, L. R. 1990. "An alternative "description of personality": The big-five factor structure." Journal of Personality \& Social Psychology 1216-1229.

iEduNote. 2021. Difference between Values and Attitudes. Accessed September 9, 2021. https://www.iedunote.com/values-attitudes-difference.

Clay, Thomas, and Kenneth R. Fleischmann. 2012. "The relationship between human values and attitudes toward the Park51 and nuclear power controversies." Proceedings of the American Society for Information Science and Technology 1-10.

Goldberg, L. R. 1990. "An alternative "description of personality": The big-five factor structure." Journal of Personality \& Social Psychology 1216-1229.

iEduNote. 2021. Difference between Values and Attitudes. Accessed September 9, 2021. https://www.iedunote.com/values-attitudes-difference.

Kristiansen, C. M., \& Zanna, M. P. (1988). Justifying attitudes by appealing to values: A functional perspective. British Journal of Social Psychology, 27(3), 247-256. https://doi.org/10.1111/j.20448309.1988.tb00826.x

Lusk, E. J., \& Oliver, B. L. (1974). Research notes. American manager's personal value systemsrevisited. Academy of Management Journal, 17 (3), 549-554.

Maio, G. R., \& Olson, J. M. (1994). Value-attitude-behavior relations: The moderating role of attitude functions. British Journal of Social Psychology, 33(3), 301-312. https://doi.org/10.1111/j.20448309.1994.tb01027.x 